\title{
Easy and Efficient DNA Extraction from Woody Plants for the Detection of Phytoplasmas by Polymerase Chain Reaction
}

\author{
Margaret J. Green and Dan A. Thompson, Centre for Plant Health, Canadian Food Inspection Agency, 8801 East \\ Saanich Road, Sidney, BC Canada V8L 1H3, and Donald J. MacKenzie, Canadian Food Inspection Agency, 59 \\ Camelot Drive, Nepean, ON Canada K1A 0Y9
}

\begin{abstract}
Green, M. J., Thompson, D. A., and MacKenzie, D. J. 1999. Easy and efficient DNA extraction from woody plants for the detection of phytoplasmas by polymerase chain reaction. Plant Dis. 83:482-485.

A simple and efficient procedure for the extraction of high-quality DNA from phytoplasmainfected woody and herbaceous plants for polymerase chain reaction (PCR) detection is described. This procedure does not require phenol, chloroform, or alcohol for the precipitation of nucleic acids. Herbaceous and woody plant material are extracted in an identical manner with no additional purification or enrichment steps required. The method utilizes commercially available microspin-column matrices, and the extraction of total DNA can be achieved in less than $1 \mathrm{~h}$. The method has been used to successfully purify phytoplasma DNA from whole leaves, leaf petioles and midribs, roots, and dormant wood from a diverse selection of plant material. The phytoplasmas detected by PCR include pear decline, western X-disease, peach yellow leaf roll, peach rosette, apple proliferation, Australian grapevine yellows, and Vaccinium witches'-broom.
\end{abstract}

Phytoplasmas, formerly called mycoplasmalike organisms, are associated with and believed to be the causative agent of many plant diseases (17). They are grafttransmissible but cannot be transmitted by sap inoculation or cultured in vitro. Phytoplasmas have been diagnosed by woodyhost bioassays (4), electron microscopy $(11,17)$, serology, and fluorescent staining (DAPI) $(3,4,11)$; however, these methods have limited sensitivity and are not suitable for large sample numbers. Polymerase chain reaction (PCR) is an effective tool for the detection of phytoplasmas in their plant hosts $(1,5,6,8,12,14,18,20)$.

Typically, phytoplasma DNA is extracted from symptomatic leaf tissue of naturally infected woody and herbaceous hosts and from experimentally infected periwinkle (Catharanthus roseus) using a phytoplasma enrichment and cetyltrimethylammonium bromide (CTAB) extraction procedure (1), or a modification of the DNA isolation procedure originally

Corresponding author: M. J. Green

E-mail: greenmg@em.agr.ca

Accepted for publication 22 December 1998.

Publication no. D-1999-0301-04S

This article is in the public domain and not copyrightable. It may be freely reprinted with customary crediting of the source. The American Phytopathological Society, 1999. described by Doyle and Doyle (7). However, extraction of phytoplasma DNA from grapevine plant material has been difficult to achieve because the phytoplasmas are present at low titers (5). Other difficulties include isolating phytoplasma DNA from woody plant tissue which is free from enzyme inhibitory plant polyphenolic and polysaccharide compounds. As more laboratories adopt PCR-based detection protocols, there is a need for the development of extraction methods that can accommodate herbaceous and woody plant material, different tissue types (i.e., leaf, scionwood, or root), and can be easily performed at the bench using microtube-type formats.

Some researchers working with Vitis spp. (5) have used modifications of Kirkpatrick's phytoplasma enrichment procedure (10); whereas others (2) have used Steenkamp's (21) modified Doyle and Doyle procedure. These DNA purification methods require the use of organic solvents, alcohol precipitation of nucleic acid, and use volumes which are not compatible with microcentrifugation. The reliable detection of phytoplasmas in large numbers of woody host plants, such as those in a certification program or a regulatory testing process, is hindered by the extraction methodologies of current protocols. The Centre for Plant Health tests fruit crops for virus and viruslike diseases, including phytoplasmas, and rapid and sensitive tests are needed to augment the woody-host bioassays traditionally used for phytoplasma detection.

In this report, we describe the modification and use of a commercially available plant DNA extraction kit (DNeasy, Qiagen, Inc., Mississauga, ON) for the development of a PCR method for the detection of phytoplasmas. This simple, quick, and reliable method is well-suited for largescale sample processing. Variations of this methodology for the extraction of RNA and detection of viral pathogens in woody plants such as grapevine, tree fruit, and small fruit varieties are also in current use $(15,16)$.

\section{MATERIALS AND METHODS}

Sources of isolates. Total DNA was extracted from healthy control plants and from experimentally infected host plants. Tree fruit phytoplasmas were transmitted by bottle-grafting infected scion wood to virus-tested pear (Pyrus communis), peach (Prunus persica), cherry (Prunus avium), and apple (Malus $\times$ domestica) rootstocks, and were held under quarantine conditions at the Centre for Plant Health. Pear decline (PD), western X disease (WX), and peach yellow leaf roll (PYLR) infected scions were received from B. C. Kirkpatrick (University of California, Davis). Apple proliferation (AP) and peach rosette (PR) infected scions were provided by W. Jelkmann (Institut für Pflanzenschutz im Obstbau, Dossenheim, Germany) and S. Scott (Clemson University, Clemson, SC), respectively. Leaves from grapevine (Vitis vinifera 'Chardonnay') infected with Australian grapevine yellows (AGY) were supplied by R. Bonfiglioli (University of Adelaide, Adelaide, Australia). Periwinkle infected with Vaccinium witches'-broom (VAC) was received from E. Seemüller (Institut für Pflanzenschutz im Obstbau). A symptomatic field potato, naturally infected with witches'-broom phytoplasma, was donated by P. Ellis (Phyto Diagnostics Company Ltd., Sidney, BC).

DNA extraction. Leaf petioles and midribs, scionwood, or root tissue were used for total DNA extraction from fruit trees; leaf petioles and midribs were used from grapevine; and young symptomatic leaves were used for extraction from periwinkle. 
Scionwood of 2- to $3-\mathrm{cm}$ lengths was "shaved" using a mechanical pencil sharpener (APSCO standard sharpener) attached to a variable speed hand drill (Fig. 1). Extra shaving heads were purchased, and a hexagonal shaft was permanently inserted. The shaft fits into a hexagonal socket on the drill so the shaving heads could be quickly removed for washing in a detergent solution, rinsed in water, and then dried with compressed air. Root tissue was prepared for homogenization by crushing in a plastic mesh-lined sample bag using a hammer.

Approximately 0.5 to $0.6 \mathrm{~g}$ of leaf tissue, bark shavings, or root tissue was placed in a sample bag (Agdia, Elkhart, IN) suitable for use with a Homex 5 homogenizer-extractor (Bioreba, South Bend, IN) and homogenized with $5 \mathrm{ml}$ of CTAB extraction buffer (3) composed of $100 \mathrm{mM}$ Tris, $\mathrm{pH}$ 8.0, $1.4 \mathrm{M} \mathrm{NaCl}, 50 \mathrm{mM}$ EDTA, $\mathrm{pH}$ 8.0, 2.5\% (wt/vol) CTAB, 1\% (wt/vol) polyvinylpyrrolidone (PVP-40), and $0.2 \%$ (vol/vol) 2-mercaptoethanol (added just prior to use). The homogenate $(0.5 \mathrm{ml})$ was transferred to a 1.5-ml microcentrifuge tube, mixed (by inversion) with $22 \mu \mathrm{l}$ of RNase A $(20 \mathrm{mg} / \mathrm{ml})$, and incubated at $65^{\circ} \mathrm{C}$ with gentle shaking (800 rpm) using an Eppendorf Thermomixer (VWR Canlab, Mississauga, ON) for 25 to $35 \mathrm{~min}$. Then $162 \mu \mathrm{l}$ of AP2 buffer (Qiagen) was added, mixed by inversion, and placed on ice for 5 min. The entire contents were applied onto a QIAshredder (Qiagen) column sitting in a 2-ml collection tube and microcentrifuged at maximum speed for $2 \mathrm{~min}$ in an Eppendorf microcentrifuge. The column flowthrough $(450 \mu \mathrm{l})$ was transferred, without disturbing the cell-debris pellet, to a new 1.5-ml microcentrifuge tube and mixed, by inversion, with $225 \mu$ of AP3 buffer (Qiagen) and $450 \mu$ of $95 \%$ ethanol. Then, $650 \mu \mathrm{l}$ of this mixture was applied onto a DNeasy (Qiagen) column and microcentrifuged at $8,000 \times g$ for $1 \mathrm{~min}$. The flowthrough was discarded, and the microcentrifugation was repeated with the remaining sample (optional). The column was transferred to a clean 2-ml collection tube, and $500 \mu \mathrm{l}$ of AW (Qiagen) buffer was applied to the column and washed through by microcentrifugation at $8,000 \times$ $g$ for $1 \mathrm{~min}$. The flowthrough was discarded, and an additional $500 \mu \mathrm{l}$ of AW buffer was added to the column, followed by microcentrifugation at maximum speed for $2 \mathrm{~min}$. The column was transferred to a new $1.5-\mathrm{ml}$ microcentrifuge tube and the DNA eluted with $100 \mu \mathrm{l}$ of prewarmed $\left(65^{\circ} \mathrm{C}\right) \mathrm{AE}$ (Qiagen) buffer and microcentrifuged at $8,000 \times g$ for $1 \mathrm{~min}$. The DNA extracts were heated at $95^{\circ} \mathrm{C}$ for $5 \mathrm{~min}$ then placed on ice for 5 to $10 \mathrm{~min}$. The DNA was stored at $-80^{\circ} \mathrm{C}$ until ready for PCR analysis.

PCR amplification conditions. PCR was performed using native Taq DNA polymerase (Gibco/BRL, Canadian Life
Technologies, Burlington, ON) and total DNA prepared from either leaf tissue, bark shavings, or root tissue. The sequences of the PCR primers P1 and P7 have been previously published by Deng and Hiruki (6) and Schneider et al. (19), respectively, and were synthesized by Genosys Biotechnologies Inc., The Woodlands, TX. The sequence of the forward primer, P1, is 5'AAGAGTTTGATCCTGGCTCAGGATT$3^{\prime}$ and of the reverse primer, $\mathrm{P7}$, is 5'CGTCCTTCATCGGCTCTT-3'. The concentrations of components in the PCR master mix were based upon a final reaction volume of $25 \mu \mathrm{l}$. In a $0.2-\mathrm{ml}$ thinwalled PCR tube, $2.5 \mu$ of undiluted DNA extract was mixed with $22.5 \mu$ of PCR master mix, composed of $1 \times$ PCR buffer (20 mM Tris, pH 8.4, $50 \mathrm{mM} \mathrm{KCl}$ ) (Gibco/BRL), 2.5\% (wt/vol) sucrose, 0.125 $\mathrm{mM}$ cresol red, $0.2 \mathrm{mM}$ dNTPs (magnesium balanced), $2.0 \mathrm{mM} \mathrm{MgCl}_{2}$, $0.5 \mu \mathrm{M}$ primer $\mathrm{P} 1,0.5 \mu \mathrm{M}$ primer $\mathrm{P} 7$, and $0.05 \mathrm{U} / \mu \mathrm{l} \mathrm{Taq}$ DNA polymerase. Sucrose and cresol red were added to the master mix as a density modifying agent and a tracking dye, respectively, in order to facilitate the direct loading of reaction mixtures onto agarose gels following amplification. Amplification conditions consisted of 35 cycles of the following steps: denaturation for $45 \mathrm{~s}$ at $94^{\circ} \mathrm{C}$, annealing for $1 \mathrm{~min}$ at $55^{\circ} \mathrm{C}$, extension for $2 \mathrm{~min}$ at $72^{\circ} \mathrm{C}$. A final extension period of $5 \mathrm{~min}$ at $72^{\circ} \mathrm{C}$ was included to ensure complete extension of the amplified product. PCR was carried out using a Stratagene Robocycler 96 Gradient Temperature Cycler fitted with a Hot
Top assembly (Stratagene, La Jolla, CA). Samples were held at either 6 or $-30^{\circ} \mathrm{C}$ until agarose gel electrophoresis. A portion $(18 \mu \mathrm{l})$ of each reaction mixture was loaded into the wells of a $1.8 \%$ agarose gel and subjected to electrophoresis for $1.0 \mathrm{~h}$ in $1 \times$ TPE buffer (90 mM Tris-phosphate, $\mathrm{pH}$ 8.2 , and $2 \mathrm{mM}$ EDTA) at $75 \mathrm{~V}$. The PCR products were visualized by UV transillumination. Both the agarose gel and the electrophoresis buffer contained $0.5 \mu \mathrm{g}$ of ethidium bromide per $\mathrm{ml}$. The sizes of amplified DNA products were determined using DNA Molecular Weight Markers VI (Boehringer Mannheim-Canada, Laval, Que.).

\section{RESULTS AND DISCUSSION}

The methodology described here has facilitated the detection of phytoplasmas in their woody hosts using PCR. The method has been used successfully with leaf petioles and midribs from apple, cherry, peach, pear, and grapevine woody host plants and whole leaves from periwinkle. Phytoplasmas have also been detected in dormant wood and roots from pear, cherry, and peach. Fresh or frozen plant tissue (stored at $-80^{\circ} \mathrm{C}$ ) can be used in the DNA extraction with no qualitative difference in the resultant extract's purity. The DNA extraction protocol described makes use of the Homex 5 homogenizer for tissue preparation, in combination with the commercially available Plant DNeasy kit. This piece of equipment allows for semiautomated sample homogenization, and consequently, eliminates the need for tedious and time-

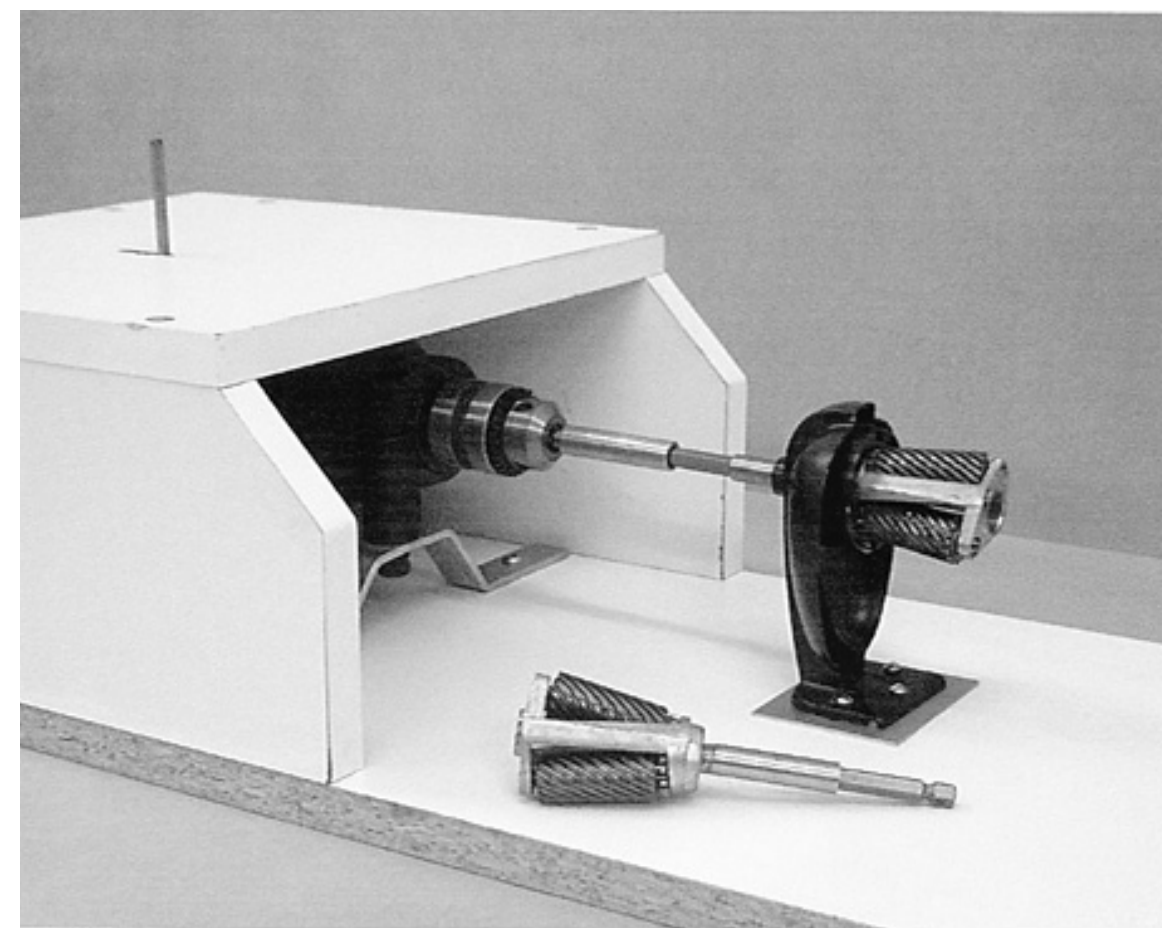

Fig. 1. Modified pencil sharpener used for grinding bark from dormant cuttings. The shaving heads are easily removed for cleaning between samples. The lever protruding from the box controls the trigger on the variable speed drill. Bark shavings are collected on a paper towel placed on a V-shaped holder under the shaving head. 
consuming initial sample preparation, such as grinding in liquid nitrogen or cutting plant tissue into small pieces. The CTAB extraction buffer (3) is a modification of the original buffer described by Doyle and Doyle (7), and when used in place of the extraction buffer supplied with the commercial kit, the protocol is easily adapted to larger amounts of tissue sample.

The P1/P7 primer pair will amplify rDNA from a wide variety of phytoplasmas but will not amplify products from healthy plants at the expected molecular weight (19). Amplification using primers P1 and P7 produces a product that is approximately 1,800 bp (Fig. 2) and contains the entire 16S rRNA gene plus the $16 / 23 \mathrm{~S}$ spacer region. Because the 1,800-bp amplicon contains the sequences targeted by other group-specific or phytoplasma-specific primers, nested PCR can easily be performed on the P1/P7 primer pair amplification product (data not shown).

The use of one-tenth reaction volume of DNA extract as template in the PCR reactions results in a readily detected product of the expected molecular weight as shown in Figure 2. No amplified product at the expected size was detected in the healthy tissue. We did observe nonspecific amplification in some of the sample preparations, although these faint bands were all at lower molecular weights than the expected PCR product. However, compared with the other samples, the amplification product yield from the grape and apple tissue extracts was relatively lower, resulting in weaker bands observed in the agarose gel. The AGY-infected grapevine leaf tissue sampled was highly symptomatic for phytoplasma infection and was collected in midsummer at a time that is considered optimal for higher phytoplasma titers. We have not yet determined if these results were actually due to low phytoplasma concentration in the tissue sampled, or whether the PCR reaction conditions could be improved upon specifically for grapevine and apple tissue.
The described procedure has been tested many times and is routinely used in our facility for detection of phytoplasmas. This same method also detected potato witches'-broom phytoplasma in a naturally infected field potato sample (data not shown). Currently, we are testing the efficacy of this method using sample tissue from small fruits such as strawberry and lingonberry. Although phytoplasmas were detected in dormant wood and root tissue of tree fruit material, the most reliable source of phytoplasma DNA was from symptomatic leaves or leaf petioles and midribs. Further tests need to be performed using various tissue types to determine their reliability as samples.

In an effort to promote the use of PCR detection in testing situations that require large-scale sampling of plant material, such as in certification programs, pathogen surveys, and other phytoplasma studies, researchers are continually developing nucleic acid extraction procedures that are simple, rapid, cost effective, and minimize the use of organic solvent extractions and alcohol precipitations, thereby reducing the amount of sample handling. The best suited extraction procedures are those that can be carried out in a microcentrifuge. There are other commercial sources of microspin-column based kits, one of which we have briefly tried with similar results (NucleoSpin Plant Kit, Clonetech Laboratories, Palo Alto, CA) (data not shown). Levy et al. (13) used a polymeric matrix (GeneReleaser, BioVentures Inc., Murfreesboro, TN) to extract DNA and RNA from infected plant tissue. Firrao and Locci (9) describe a simplified DNA purification method that also makes use of microspin technology for the detection of phytoplasmas. Their method uses a resin (Bio-Rad Instagene DNA purification matrix; BioRad Laboratories, Richmond, CA), which also eliminates the need for organic solvent extraction and DNA alcohol precipitation. Their technique, however, is restricted to the use of fresh plant material because samples stored at $-80^{\circ} \mathrm{C}$ prior to extraction

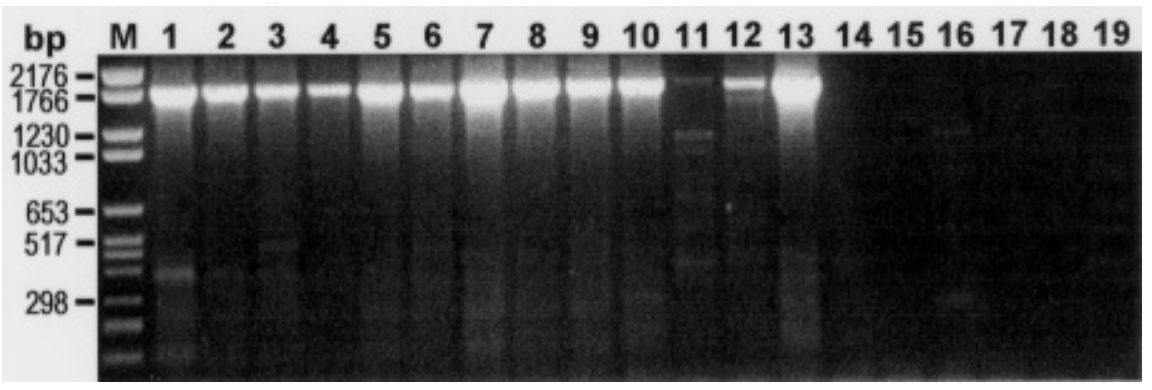

Fig. 2. Agarose gel electrophoresis showing polymerase chain reaction (PCR) detection of phytoplasmas in pear decline infected pear (lanes 1 to 3), peach yellow leaf roll infected peach (lanes 4 to 6 ), western $X$ disease infected cherry (lanes 7 to 9), peach rosette infected peach (lane 10), apple proliferation infected apple (lane 11), Australian grapevine yellows infected grape (lane 12), and Vaccinium witches'-broom infected periwinkle (lane 13) in total DNA extracts from either leaf petioles and midribs (lanes 1, 4, 7, 11,12), whole leaves (lane 13), dormant wood (lanes 2, 5, 8, 10), or root tissue (lanes 3,6,9). Healthy control samples shown are pear (lane 14), peach (lane 15), cherry (lane 16), apple (lane 17), grape (lane 18), and periwinkle (lane 19). produce brown extracts that can not be amplified. Recently, a microcentrifugescale procedure for extracting nucleic acids was developed by Zhang et al. (22); and although it does requires the use of organic solvents, it is not dependent upon any proprietary commercial product.

The DNA extraction method and PCR protocol for the detection of phytoplasmas described in this paper is well suited for testing large numbers of samples, can be used with leaf, root, and dormant wood tissue, and yields sufficient DNA for up to 40 PCR reactions. The extraction method is quick and easily manipulated, and the use of organic solvents and alcohol precipitation is unnecessary. In our laboratories, as many as 36 samples can be processed and ready for PCR amplification in less than $2 \mathrm{~h}$. Consequently, the entire protocol for phytoplasma detection, from DNA extraction to gel electrophoresis and visual documentation, can be performed in 1 day.

\section{ACKNOWLEDGMENTS}

We gratefully acknowledge the assistance of the staff at the Centre for Plant Health (Sidney, BC). We also thank B. C. Kirkpatrick (University of California, Davis), E. Seemüller and W. Jelkmann (Institut für Pflanzenschutz im Obstbau, Dossenheim, Germany), R. Bonfiglioli (University of Adelaide, Adelaide, Australia), S. Scott (Clemson University, Clemson, SC), and P. Ellis (Phyto Diagnostics Company Ltd., Sidney, BC) for providing samples of phytoplasma-infected plant material.

\section{LITERATURE CITED}

1. Ahrens, U., and Seemüller, E. 1992. Detection of DNA of plant pathogenic mycoplasmalike organisms by a polymerase chain reaction that amplifies a sequence of the $16 \mathrm{~S}$ rRNA gene. Phytopathology 82:828-832.

2. Bonfiglioli, R. G., Magarey, P. A., and Symons, R. H. 1995. PCR analysis confirms an expanded symptomatology for Australian grapevine yellows. Aust. J. Grape Wine Res. 1:71-75.

3. Chen, K. H., Credi, R., Loi, N., Maixner, M. and Chen, T. A. 1994. Identification and grouping of mycoplasmalike organisms associated with grapevine yellows and clover phyllody diseases based on immunological and molecular analyses. Appl. Environ. Microbiol. 60:1905-1913.

4. Cornaggia, D., Gentit, P., Boyé, R., and Desvignes, J. C. 1995. A new phytoplasma disease of apricot trees: The peach vein clearing. Acta Hortic. 386:448-453.

5. Daire, X., Boudon-Padieu, E. Berville, A., Schneider, B., and Caudwell, A. 1992. Cloned DNA probes for detection of grapevine Flavescence doree mycoplasma-like organism (MLO). Ann. Appl. Biol. 121:95-103.

6. Deng, S., and Hiruki, C. 1991. Amplification of $16 \mathrm{~S}$ rRNA genes from culturable and nonculturable Mollicutes. J. Microbiol. Methods 14:53-61.

7. Doyle, J. J., and Doyle, J. L. 1990. Isolation of plant DNA from fresh tissue. BRL Focus 12(1):13-15.

8. Firrao, G., Gobbi, E., and Locci, R. 1993. Use of polymerase chain reaction to produce oligonucleotide probes for mycoplasmalike organisms. Phytopathology 83:602-607.

9. Firrao, G., and Locci, R. 1993. Rapid preparation of DNA from phytopathogenic mycoplasma-like organisms for polymerase chain 
reaction analysis. Lett. Appl. Microbiol. 17:280-281.

10. Kirkpatrick, B. C., Stenger, D. C., Morris, T. J., and Purcell, A. H. 1987. Cloning and detection of DNA from a nonculturable plant pathogenic mycoplasma-like organism. Science 238:197-200

11. Lee, I.-M., and Davis, R. E. 1992. Mycoplasmas which infect plants and insects. Pages 379-390 in: Mycoplasmas: Molecular Biology and Pathogenesis. J. Maniloff, R. N. McElhaney, L. R. Finch, and J. B. Baseman, eds. American Society for Microbiology, Washington, DC.

12. Lee, I.-M., Hammond, R. W., Davis, R. E., and Gundersen, D. E. 1993. Universal amplification and analysis of pathogen $16 \mathrm{~S}$ rDNA for classification and identification of mycoplasmalike organisms. Phytopathology 83:834-842.

13. Levy, L., Lee, I.-M., and Hadidi, A. 1994. Simple and rapid preparation of infected plant tissue extracts for PCR amplification of virus, viroid, and MLO nucleic acids. J. Virol. Methods 49:295-304.

14. Lorenz, K.-H., Schneider, B., Ahrens, U., and Seemuiller, E. 1995. Detection of the apple proliferation and pear decline phytoplasmas by PCR amplification of ribosomal and nonribosomal DNA. Phytopathology 85:771-776.

15. MacKenzie, D. J., Johnson, R. C., and Warner, C. 1996. Incidence of four important viral pathogens in Canadian vineyards. Plant Dis. 80:955-958.

16. MacKenzie, D. J., McLean, M. A., Mukerji, S., and Green, M. 1997. Improved RNA extraction from woody plants for the detection of viral pathogens by reverse transcriptionpolymerase chain reaction. Plant Dis. 81:222226.

17. McCoy, R. E., Caudwell, A., Chang, C. J., Chiykowski, L. N., Cousin, M. T., Dale, J. L., de Leeuw, G. T. N., Golino, D. A., Hackett, K. J., Kirkpatrick, B. C., Marwitz, R., Petzold, H., Sinha, R. C., Sugiura, M., Whitcomb, R. F., Yang, I. L., Zhu, B. M., and Seemüller, E. 1989. Plant diseases associated with mycoplasma-like organisms. Pages 545-640 in: The Mycoplasmas. Vol. 5. Spiroplasmas, Acholeplasmas, and Mycoplasmas of Plants and Arthropods. R. F. Whitcomb and J. G. Tully, eds. Academic Press, San Diego, CA.

18. Schaff, D., Lee, I.-M., and Davis, R. E. 1992 Sensitive detection and identification of my- coplasma-like organisms in plants by polymerase chain reactions. Biochem. Biophys. Res. Commun. 186:1503-1509.

19. Schneider, B., Seemüller, E., Smart, C. D., and Kirkpatrick, B. C. 1995. Phylogenetic classification of plant pathogenic mycoplasma-like organisms or phytoplasmas. Pages 369-380 in: Molecular and Diagnostic Procedures in Mycoplasmology. Vol. 1. S. Razin and J. G. Tully, eds. Academic Press, San Diego, CA.

20. Smart, C. D., Schneider, B., Blomquist, C. L., Guerra, L. J., Harrison, N. A., Ahrens, U., Lorenz, K.-H., Seemüller, E., and Kirkpatrick, B C. 1996. Phytoplasma-specific PCR primers based on sequences of the 16S-23S rRNA spacer region. Appl. Environ. Microbiol. 62:2988-2993.

21. Steenkamp, J., Wiid, I., Lourens, A., and Van Helden, P. 1994. Improved method for DNA extraction from Vitis vinifera. Am. J. Enol. Vitic. 45:102-106.

22. Zhang, Y.-P., Uyemoto, J. K., and Kirkpatrick, B. C. 1998. A small-scale procedure for extracting nucleic acids from woody plants infected with various phytopathogens for PCR assay. J. Virol. Methods 71:45-50. 